\title{
В0ЗМОЖНОСТИ РАЗВИТИЯ ДОСУДЕБНОГО УРЕГУЛИРОВАНИЯ СПОРОВ И МЕДИАТИВНЫХ ТЕХНОЛОГИЙ В РОССИЙСКОЙ ФЕДЕРАЦИИ С УЧЕТОМ ЗАРУБЕЖНОГО ОПЫТА
}

\section{OPPORTUNITIES FOR THE DEVELOPMENT OF PRE-TRIAL DISPUTE RESOLUTION AND MEDIATION TECHNOLOGIES IN THE RUSSIAN FEDERATION, TAKING INTO ACCOUNT FOREIGN EXPERIENCE}

\section{G. Baranov}

Summary. The article considers the possibilities of development of pretrial dispute settlement, as well as mediation technologies in the Russian Federation, taking into account foreign experience.

The research methodology consists of comparative, formal-legal, analytical methods, and a systematic approach.

The findings of the study can be used in law enforcement practice, as well as in the educational process.

Keywords: pre-trial settlement; mediation; civil procedure.

\author{
Баранов Геннадий Александрович \\ Заместитель председателя, Березниковский \\ городской суд Пермского края \\ GennadyyBaranov@yandex.ru
}

Аннотация. В статье рассматриваются возможности развития досудебного урегулирования споров, а также медиативных технологий в Российской Федерации с учетом зарубежного опыта.

Методологию исследования составили сравнительный, формально-юридический, аналитический методы, системный подход.

Выводы исследования могут быть использованы в правоприменительной практике, а также в учебном процессе.

Ключевые слова: досудебное урегулирование; медиация; гражданский процесс.

поративная, ведь договорившись, стороны прекращают судебное разбирательство. Задачей же законодателя является введение и развитие принципов благоприятствования и способствования примирению противоборствующих сторон [5].

Еще одна причина, по которой законодатель очевидно заинтересован в развитии досудебных и примирительных процедур - это стоимость организации суда для государства. На данное обстоятельство неоднократно обращали внимание высшие руководители судебной власти в России, например - в 2010 году на совещании федеральных и мировых судей Краснодарского края, состоявшемся в Краснодаре, озвучено, что в семь тысяч рублей обходится государству один день при рассмотрении гражданских дел, в 27 тысяч - уголовных и в 170 тысяч, когда дело рассматривается судом присяжных. При этом, предмет исковых требований, зачастую, несущественен [10].

В настоящее время медиация как правовое явление прочно вошло в правоприменительную деятельность, этому явлению посвящается все большее внимание, публикуются научные труды и исследования. При этом, 
к сожалению, медиация пока что не оказывает сколь-нибудь существенного воздействия на разрешение споров имеющихся споров между сторонами, и, в целом, можно констатировать, что государственные органы и суд относятся к нему в определенной степени с опаской и недоверием.

Следует отметить, что законодатель предпринимает определенные усилия по внедрению медиации в правовую действительность, так, принят Федеральный закон от 27.07.2010 № 193-Ф3 «Об альтернативной процедуре урегулирования споров с участием посредника (процедуре медиации)» [3].

В развитие данного закона также принят, в частности, Федеральный закон от 26.07.2019 № 197-Ф3 «О внесении изменений в отдельные законодательные акты Российской Федерации», в соответствии со ст. 5 которого Гражданский процессуальный кодекс Российской Федерации дополнен главой 14.1 «Примирительные процедуры. Мировое соглашение» [1].

Вместе с тем, данных усилий, очевидно, недостаточно, до настоящего времени медиация остается загадочным и во многом непонятным явлением. Каким образом возможно повысить степень информированности и вовлеченности граждан и юридических лиц о данной процедуры? Очевидно, что путем повышения правовой культуры и правосознания можно и нужно идти, однако, представляется, что необходимо также и создать условия, которые бы автоматически понуждали стороны к медиативным технологиям до обращения их в суд.

К таким условиям, по мнению автора относится, например, введение и повышение сумм государственной пошлины, подлежащей уплате при обращении в суд. При этом, предусмотрение льгот по уплате государственной пошлины для лиц, которые прошли процедуру медиации до обращения в суд. В чем видится обоснованность данного предложения? Прежде всего, как ни парадоксально, но - в доступности судопроизводства.

Если обратиться к сравнительной характеристике величины уплаты государственной пошлины в России и некоторых европейский странах, то мы увидим, что в России она составляет одну из самых меньших величин [9].

Согласно ч. 1 ст. 154 Гражданского процессуального кодекса РФ, гражданские дела рассматриваются и разрешаются судом до истечения двух месяцев со дня поступления заявления в суд, если иные сроки рассмотрения и разрешения дел не установлены настоящим Кодексом, а мировым судьей до истечения месяца со дня принятия заявления к производству [1].
Между тем, например, в судах Германии срок рассмотрения дела в участковых судах (Amtsgerichte - нижний уровень судебной системы) составляет около трех месяцев для примерно 50\% дел, шесть месяцев - для 30\% дел, и 12 месяцев для 18\% дел. Средний срок рассмотрения дел в участковых судах составляет 4,6 месяца, при этом 4\% дел рассматриваются более двух лет. Суды земель (Landsgerichte) рассматривают 40\% дел в течение трех месяцев, 25\% - в течение шести месяцев, 22\% - в течение 12 месяцев, около 10\% - в течение 24 месяцев [13]. Во Франции средняя продолжительность рассмотрения гражданского дела в Суде большой инстанции (Tribunal de grande instance) составляет 8,8 месяца, в окружных судах (tribunal d'instance) - около 5 месяцев [8].

Таким образом, судебное производство в России сегодня быстро инициируется, быстро рассматривается, стороны быстро получают судебный акт, то есть, для сторон сейчас судиться дешево и быстро, отсутствует стимул для обращения к каким-либо медиативным технологиям. Безусловно, нужно обеспечивать льготы для обращения в суд для нуждающихся и социально-уязвимых слоев населения, однако, возможность концепции суда «всех для всех», безусловно, нуждается в реформировании.

Следует, безусловно, отметить положительную тенденцию в данном направлении, поскольку Федеральным законом от 26.07.2019 № 198-Ф3 в ст. 333.40 Налогового кодекса РФ внесены изменения, и, в настоящее время, при заключении мирового соглашения (соглашения о примирении), отказе истца (административного истца) от иска (административного иска), признании ответчиком (административным ответчиком) иска (административного иска), в том числе по результатам проведения примирительных процедур, в зависимости от судебной инстанции, в которой происходит рассмотрение дела, истцу (административному истцу) подлежит возврату от 70 до 30 процентов уплаченной им государственной пошлины [2]. Однако, как уже говорилось выше, данное обстоятельство хоть и стимулирует истцов отчасти к примирению, но не способствует избеганию обращения в суд с исковым заявлением.

Некоторые виды споров в настоящее время очевидно не нуждаются в судебных решениях, между тем, граждане вынуждены обращаться в суды по самым разнообразным вопросам, например - утрата права пользования жилым помещением. Как следует из статистических данных, размещенных на сайте Судебного департамента при Верховном Суде РФ, за 2019 год судами рассмотрено 205743 жилищных споров из графы «иные» [11]. В данной графе учитываются и сведения о рассмотрении судом исковых заявлений об утрате права пользования жилым помещением. 
В подавляющем большинстве случаев лица, в отношении которых инициируется судебное разбирательство, не заинтересованы в сохранении за ними данного права, их право связывается только с нахождением на регистрационном учете в жилом помещении, с которого они, в силу каких-либо причин не снимаются после заключения сделок с новым собственником - нехватка времени, забывчивость, выезд за пределы населенного пункта, а, иногда, и страны прежнего проживания. Очевидно, что в данном случае возможно принятие административного решения о снятии подобных граждан с регистрационного учета по заявлению новых собственников, например, соответствующими подразделениями органов внутренних дел. Безусловно, для исключения злоупотреблений со стороны недобросовестных заявителей следует предусмотреть определенную проверку доводов со стороны административного органа, например - извещение лица, в отношении которого поступило заявление о снятии его с регистрационного учета, по месту регистрации, путем информирования через информационный портал Госуслуг, сверки данных о проживании данного лица с иными государственными структурами. Также стоит предусмотреть, что, в том случае, если административный орган усмотрит наличие спора о праве, он вправе прекратить производство по заявлению лица, обратившегося с ним, и разъяснить ему право на обращение в суд. В этом случае, при обращении в суд с заявлением об утрате права пользования жилым помещением, гражданин также должен будет предоставить сведения о его предварительном соответствующем обращении в государственный орган.

Второй яркий пример - расторжение брака мировыми судьями. Напомним, в настоящее время, если у супругов имеются совместные дети и между ними отсутствует спор о порядке их воспитания и месте жительства обязаны обратиться к мировому судье с заявлением о расторжении брака. Опять-таки, по данным, размещенным на сайте Судебного департамента при Верховном Суде РФ, за 2019 год судами рассмотрено 333800 дел о расторжении брака супругами, имеющими детей, и 77902 дел о расторжении брака супругами, не имеющими детей либо дети которых являются совершеннолетними [11].

Автору статьи, несколько лет проработавшему мировым судьей, данное положение законодательства представляется неоправданным и требующим корректировки, необходимость судебного решения в данном случае минимальна. Неужели административный орган (в данном случае - ЗАГС) не сможет принять решение о разводе сторон? Безусловно, сможет. Далее, установление факта. Например, достаточно популярным судебным производством сейчас является установление факта принадлежности правоустанавливающего документа гражданину для вступления в наследство, например свидетельства о праве собственности. Данные дела рассматриваются по правилам главы 28 Гражданского процессуального кодекса РФ [1]. Зачастую, в данных документах неумышленно допускаются ошибки в паспортных данных владельцев, адресных данных и иные, вроде бы незначительные, но препятствующие выдаче свидетельства о праве на наследство. Очевидно, что данные факты вполне возможно установить нотариусу без инициирования заинтересованным лицом процедуры судебного разбирательства. Более того, нотариус, по мнению автора статьи, вправе установить и факт принятия наследником наследства. И лишь в случае возникновения спора о праве отказать наследнику в выдаче свидетельства о праве на наследство и рекомендовать ему обратиться в суд с заявлением. Аналогичные примеры можно привести в и иных сферах правоотношений.

Одной из проблем в применении медиативных технологий является отсутствие профессионального корпуса медиаторов в России, а также платность проведения процедур медиации. Как вариант разрешения данной проблемы - внедрение организации проведения медиативных процедур в деятельность различных ассоциаций и союзов. Так, например, в настоящее время в России существуют более 70 различных ассоциаций и объединений предпринимателей [12]. Представляется, что вполне возможно предусмотреть досудебный порядок обращения потребителей в случае их несогласия с действиями изготовителя, продавца, в соответствующую ассоциацию, которая организовывала бы рассмотрение такого спора. Такая практика применяется, например, в Исландии [7]. По мнению автора, это способствовало бы решению таких задач как урегулирование конфликта, пропаганда внесудебных путей разрешения споров. Возможно, стоит также рассмотреть вариант аккредитации данных ассоциаций в торгово-промышленной палате РФ (или ином органе, учреждении) на право ведения медиативной деятельности, и, соответственно, выработке определенных стандартов по котором должно производиться рассмотрение указанных споров. Оплату рассмотрения таких споров возможно субсидировать со стороны государства — полностью либо частично. В Скандинавских странах, например, деятельность Бюро по рассмотрению жалоб потребителей полностью оплачивает государство [5].

В целях стимулирования сторон к переговорам и урегулированию спорных взаимоотношений стоит предусмотреть меры для содействия добровольному исполнению уже вынесенного судебного решения. Данная практика была распространена при рассмотрении споров в Древней Греции [5]. Так, например, представляется оправданным, что, в том случае, если стороны после вынесения судебного решения в ходе исполнительного 
производства заключили мировое соглашение, то в этом случае с должника не взыскивается исполнительский сбор, а в случае его удержания к этому времени - данная сумма подлежит возвращению.

Нельзя не высказаться и относительно такого вопроса как введение обязательной медиации по некоторым категориям дел в качестве досудебной процедуры. В настоящее время имеется две точки зрения, а именно - одна часть авторов пропагандирует введение обязательной медиации, вторая не считает это возможным. В качестве обоснования необходимости введения обязательной медиации приводится пример зарубежных стран, в частности - стран Европы, в которых данные положения закреплены в законодательстве (Франция, Великобритания), а также то, что именно с законодательным закреплением этого началось быстрое развитие процедур медиации, поскольку стороны стали сталкиваться с ними в силу законодательного предписания. Противники данного подхода отмечают, что сама процедура медиации предполагает добровольность (ссылку на кого-нибудь), таким образом, обязание сторон участвовать в ней будет дискредитировать принципы медиации. Кроме того, отмечается, что в настоящее время в России отсутствует подготовленный корпус медиаторов, тем самым, введение обязательной медиации будет лишь декларативной мерой, которая будет нереализуемой [6]. Аргументы сторон достаточно весомые, но автор, все-таки, придерживается мысли о необходимости обязательной медиации по некоторым категориям дел, например, в сфере семейных правоотношений.

Прежде всего, хочется обратиться к мысли Алексеева С.С., высказанной им в книге «Восхождение к праву. Поиски и решения.», а именно, что право по своей природе не только регулирует общественные отношения, но и способно, путем «опережающих» акций именно в области права - авангардного достижения тех рубежей, которые могли бы стать ориентиром и надежной основой для плодотворного экономического и социального продвижения вперед в общем направлении демократического реформирования» [4]. То есть, законодатель в данном случае вполне может задать направление развития общественных отношений, стимулировать людей к диалогу в такой чувствительной для них сфере.

Из собственного опыта рассмотрения дел данной категории можно с уверенностью сказать, что у сторон до встречи в суде, зачастую, отсутствует какой-либо диалог. Между тем, уже на первом судебном заседании, как правило, удается найти точки соприкосновения позиций, которых оказывается совсем немало, и спор, по большому счету, продолжатся вокруг отдельных моментов. Кроме того, медиация в данной сфере является ярким примером, когда в ходе одной процедуры стороны могут решить несколько абсолютно не связанных между собой спорных вопросов - от раздела имущества до определения порядка общения с детьми. Решение же данных вопросов в суде требует значительного времени и средств, нескольких инициирования нескольких судебных производств. Процедуру медиации вполне могли бы проводить сотрудники служб по делам несовершеннолетних. Также вполне возможно введение обязательной медиации по трудовым и земельным спорам.

Резюмируя все вышесказанное, стоит констатировать, что в настоящее время варианты развития досудебного урегулирования споров, а также медиативных технологий в Российской Федерации весьма разнообразны, и, хочется надеяться, что так или иначе данные варианты будут реализованы законодателем и займут свое место в регулировании общественных отношений.

\section{ЛИТЕРАТУРА}

1. Гражданский процессуальный кодекс Российской Федерации// URL: http://www.consultant.ru/document/cons_doc_LAW_39570/ (дата 06ращения 14.06.2020)

2. Налоговый кодекс Российской Федерации URL: http://www.consultant.ru/document/cons_doc_LAW_28165/ (дата 0бращения 14.06.2020)

3. Федеральный закон от 27.07.2010 № 193-Ф3 «06 альтернативной процедуре урегулирования споров с участием посредника (процедуре медиации)»// URL: http://www.consultant.ru/document/cons_doc_LAW_103038/(дата обращения 14.06.2020)

4. Алексеев С. С. Восхождение к праву. Поиски и решения.- М.: Издательство НОРМА, 2001.

5. Давыденко Д.Л. Примирительные процедуры в европейской правовой традиции. — М.: Инфотропик Медиа, 2013.

6. Загайнова С.К. 0 комплексном подходе к развитию медиации в России [Электронный ресурс].— Ресурсный Центр медиации — Режим доступа: URL: http://mediators.ru/rus/about_mediation/news/text12/text5 (дата обращения 14.06.2020)

7. Ассоциация потребителей Исландии (Neytendasamtökin) URL: www.ns.is (дата обращения 14.06.2020)

8. В повестку дня судебной реформы: продление процессуальных сроков [Электронный ресурс].—Pravo.ru. — Режим доступа: URL: https://pravo.ru/review/ view/47313/(дата обращения 14.06.2020)

9. Доступное правосудие: сколько стоит суд в разных странах мира [Электронный ресурс]. - Pravo.ru. — Peжим доступа: URL: https://pravo.ru/review/ view/124276/(дата обращения 14.06.2020) 
10. Правосудие — дорогое удовольствие [Электронный ресурс].— Право — экспресс. — Режим доступа: URL: https://pravo-express.ru/index.php?id=78(дата обращения: 14.06.2020).

11. Сайт Судебного департамента при Верховном Суде РФ. Данные судебной статистики Режим доступа: URL: http://www.cdep.ru/index.php?id=79\&item=5258 (дата обращения 14.06.2020)

12. Сайт Торгово-промышленной палаты Российской Федерации. URL: https://tpprf.ru/ru/members/communities/association/ (дата обращения 14.06.2020).

13. Стандарты справедливого правосудия (международные и национальные практики) (под ред. Морщаковой Т.Г.) [Электронный ресурc].— URL: https:// law.wikireading.ru/10367 (дата обращения 14.06.2020)

(с Баранов Геннадий Александрович ( GennadyyBaranov@yandex.ru ).

Журнал «Современная наука: актуальные проблемы теории и практики» 